\title{
Modern Technology of Poultry Semen Cryopreservation
}

\author{
Alexander V. TKACHEV \\ $\mathrm{Ph} . \mathrm{D}$. (in Agriculture) \\ Professor \\ Senior Research Officer \\ Department of General and Private Zootechnics \\ Faculty of Technology \\ Federal State Budgetary Educational Institution of Higher Education \\ Belgorod State Agricultural University \\ 1, Vavilova str., Belgorod, 308503, the Russian Federation
}

\section{Olga L. TKACHEVA}

Ph.D. (in Agriculture)

Head Specialist

Department of Scientific Researches and Grants Organization

Federal State Budgetary Educational Institution of Higher Education

Belgorod State Agricultural University

1, Vavilova str., Belgorod, 308503, the Russian Federation

\section{Lyudmila V. GAZZAVI-ROGOZINA \\ Ph.D. (in Agriculture) \\ Associate Professor}

Department of Chemistry, Microbiology and Nutrition Hygiene

Educational and Research Institute of Food Technologies and Business

Kharkiv State University of Food Technology and Trade

333, Klochkivska str., Kharkiv, 61051, Ukraine

\author{
Tatyana V. ZUBOVA \\ Ph.D. (in Biology) \\ Professor \\ Department of Zootechnics \\ Faculty of Livestock
}

Federal State Budgetary Educational Institution of Higher Education

Kuzbass State Agricultural Academy

5, Markovtseva Str., Kemerovo, the Russian Federation

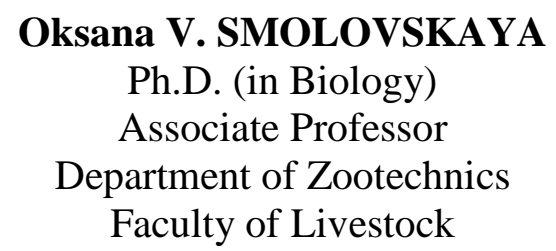

Federal State Budgetary Educational Institution of Higher Education

Kuzbass State Agricultural Academy

5, Markovtseva Str., Kemerovo, the Russian Federation

\section{Vladimir A. PLESHKOV}

Ph.D. (in Agriculture)

Associate Professor

Department of Animal Breeding and Genetics 
Faculty of Zootechnics

Federal State Budgetary Educational Institution of Higher Education

Kuzbass State Agricultural Academy

5, Markovtseva Str., Kemerovo, the Russian Federation

\section{Abstract}

This article presents results of comparison of efficiency of cryopreservation of sperm of a poultry on Belgorod and German technology and physiological features of sperm of males of birds of different kinds. Ejaculates from experimental birds were received 3 times a week by spin peritoneum massage. Efficiency of Belgorod technology of semen cryopreservation, which was modified by us for semen of birds, provided better physiological characteristics, separated ejaculates of poultry after thawing, than German technology. The mobility of rooster sperm after decontamination was $4.24 \%$ higher than that of the German technology with an increase in membrane conservation by $8.6 \%$. Cryoresistance of quail semen was also higher at application of Belgorod technology by $3.24 \%$ on mobility and by $3,26 \%$ on membrane-stabilizing properties. The efficiency of guinea fowls semen cryopreservation according to Belgorod technology in lined granules was $4.44 \%$ higher than the German analogue in terms of sperm motility, $8.87 \%$ higher in terms of integrity of plasma membranes of germ cells. Physiological characteristics of thawed turkey semen, which was prepared according to the Belgorod technology, exceeded the German analogue by $7.04 \%$ in terms of mobility and by $2.65 \%$ in the integrity of the membranes of sperm cells.

Keywords: cryopreservation; semen; physiology; poultry; Belgorod technology.

\section{Introduction}

Poultry meat is the main source of dietary protein for humans. Therefore, the world is witnessing intensive development of the poultry industry. Over the past four years, the number of poultry has increased by about $11 \%$ worldwide, due to physiological speed and relatively low feed costs compared to other animal species grown to produce meat (Blanco, Hofle, Moorhouse, Donoghue, Wildt, 2007; Blesbois, Brillard, 2007; Brillard, Beaumont, Scheller, 1998; Cengiz, Yusuf, Ilker, 2013).

Insufficient practical application of semen cryopreservation and artificial insemination of birds, which is partly due to the low efficiency of existing methods of freezing ejaculates, is a constraint on the development of the poultry industry (Dimitrov, Atanasov, Surai, Denev, 2007; Donoghue, Wishart, 2000; Douard, Hermier, Magistrini, Blesbois, 2003). In the process of freezing and thawing of ejaculates of birds a sharp decrease in physiological characteristics of spermatozoa is observed that is explained by a high level of damage of plasma membranes of sexual cells of 
birds (Fattah, Sharafi, Masoudi, Shahverdi, Najafi, 2017; Froman, 2003; Hudson, Omprakash, Premavalli, 2016). First of all, it indicates the imperfection of existing technological approaches and applied diluents for bird ejaculates (Iaffaldano, Meluzzi, 2003; Kotlowska, Dietrich, Wojtczak, Karol, Ciereszko, 2007; Kucera, Heidinger, 2018). Partially the decrease in the efficiency of cryopreservation of bird sperm is due to significant differences in sperm morphology in comparison with mammals: the length of the flagellum is 7-8 times longer than the length of the sperm head; the sperm head has an elongated, elongated shape (against oval, pear-shaped in mammals) (Long, 2006; Lukasewicz, Chrzanowska, Jerysz, Chelmonska, 2004; Mong Diep Nguyen, Alves, Grasseau, Métayer-Coustard, Praud, 2014). In addition, significant differences in semen cryoresistance of birds depending on their species and direction of productivity have been proved, despite similarity in sperm structure (Mosca, Madeddu, Sayed, Zaniboni, Cerolini, 2016; Nishimura, Fan, 2002; Noirault, Brillard, Bakst, 2006). There are studies that prove that the semen cryoresistance of roosters depends on their linear affiliation (Paranzini, Correia, de Camargo, Silva, de França, Silva, Veiga, de Souza, 2018; Partyka, Niżański, Bajzert, Łukaszewicz, Ochota, 2013). The semen of the musk spleen has a higher cryoresistance than that of the spleen of a Beijing duck (Seigneurin, Grasseau, Chapuis, Blesbois, 2013). The lowest physiological ability to withstand cryopreservation among male birds has been described in Cesar bucks (Ushiyama, Priyadarshana, Setiawan, Miyazaki, Ishikawa, 2019; Woelders, Zuilberg, Hiemstra, 2006).

In recent years, researchers at the Research Institute for Problems of Cryobiology and Cryomedicine have established certain success in cryopreservation of bird semen, despite the fact that it is still not possible to preserve more than $50 \%$ of full-grown germ cells after freezing and thawing. Alternative cryoprotectors with less cytotoxic effect are being sought, because glycerin significantly reduces the fertilization ability of poultry sperm even at $2 \%$ concentration (Dyubko, Egorov, Linnik, 2007; Linnik, Martynyuk, 2010; Linnik, 2003).

To solve the problem of increasing the efficiency of cryopreservation of bird semen we decided to modify our developed Belgorod technology of cryopreservation of mammalian semen (Tkachev, Sheremeta, Tkacheva, Rossokha, 2017; Tkachev, Tkacheva, Rossokha, 2018a; Tkachev, Tkacheva, Rossokha, 2018b), which has not been previously used for freezing and thawing of bird ejaculates, while more than $80 \%$ of the market of cryopreservation of bird semen in Russia is occupied by Western European technologies of Minitube (Germany) and IMV (France). Principal differences in the technology of firms Minitube (Germany) is that the semen is packed in pellets, and freezing is carried out in a program freezer in pairs of liquid nitrogen (minus $130^{\circ} \mathrm{C}$ ) 
with subsequent immersion in liquid nitrogen (minus $196^{\circ} \mathrm{C}$ ). The modified Belgorod technology provides for another form of semen dose (lined granule or syringe-tube), the use of the developed diluent, the use of the developed non-software freezer with passive cooling of the metal thermoblock in which there are semen doses to minus $80^{\circ} \mathrm{C}$ with subsequent immersion into liquid nitrogen (minus $196^{\circ} \mathrm{C}$ ).

The aim of the study was to study the comparative efficiency of cryopreservation of poultry semen using the Minitube technology (Germany) and the modified Belgorod technology for poultry semen.

\section{Methods}

The ejaculates were received from mature male birds (7 heads), quails ( 7 heads), guinea fowls (7 heads), male turkeys (7 heads) and goose-ganders (7 heads), which were kept in individual cells of the physiological yard of the UNIC "Agrotechnopark" of the Belgorod State Agrarian University named after V. Gorin. The structure and nutritional content of the bird's diet corresponded to the existing feeding norms for each species.

Ejaculates from experimental birds were received 3 times a week by spin peritoneum massage. Freshly obtained ejaculates determined sperm motility and the number of pathological forms of germ cells in percent, in the system Sperm Vision ("Minitube", Germany). After freeze-thawing, sperm motility was determined in percent, sperm perceptibility at $38{ }^{\circ} \mathrm{C}$ in hours. The integrity of plasma membranes of sperm of birds before and after cryopreservation was determined on DAKO Galaxy cytometer.

For dilution and cryopreservation of bird semen 2 diluents, an experimental and a control diluent were used. The control diluent was as follows: bidistilled water - $100 \mathrm{ml}$; fructose - $1.0 \mathrm{~g}$; glucose $1.0 \mathrm{~g}$; Tris-Cl - $0.195 \mathrm{~g}$; two-substituted sodium phosphorus acid - $1.1 \mathrm{~g}$; sodium glutamate - $3.0 \mathrm{~g}$; glycerin up to $8 \%$. The composition of the diluent we are developing is not disclosed, the content of dimethylacetamide cryoprotector in it was also up to $8 \%$. Each ejaculate was divided into 2 equal parts and frozen in a control and experimental diluent using German and Belgorod technology respectively. Dilution of bird ejaculates was performed with diluents with respect to $1: 1$. Then the freshly diluted ejaculates were placed on equilibration in a refrigerator at $2-5{ }^{\circ} \mathrm{C}$ for 180 minutes (control dilution agent) and 90 minutes (experiment dilution agent).

Parts of the ejaculates diluted with control diluent were frozen in $0.25 \mathrm{ml}$ pallets in the Biofreeze BV-65 automatic freezer ("Consarctic Entwicklung Und Handels GmbH", Germany). Parts of the ejaculates, which were diluted with the developed diluent, were frozen in the form of $0.25 \mathrm{ml}$ coated granules in the mammal semen freezer developed by us. 
IV International Scientific and Practical Conference "Modern S\&T Equipments and Problems in Agriculture"

The statistical processing of data was carried out using generally accepted methods of variation statistics, the reliability of differences was assessed by the Student's t-criterion (26). The tables show average $(\mathrm{M})$ and average $( \pm$ SEM) deviations. The dispersion analysis was performed using a specialized application package SPSS for Windows (non-parametric statistics) ("IBM", USA).

\section{Results}

Physiological characteristics of poultry ejaculates are presented in Table 1. From the data of the table it can be seen that in native ejaculates the greatest number of sperm with straight forward motion was observed in quails, which is $1.4 \%$ more from the sperm motility of male birds, $4.96 \%$ more $(\mathrm{p}<0.05)$ from guinea fowls, $11.42 \%$ more $(\mathrm{p}<0.01)$ from male turkeys and $22.89 \%$ more $(\mathrm{p}<0.001)$ from goose-ganders.

Table 1. Physiological characteristics of native poultry semen $(M \pm S E M, n=181)$. Nota bene. * $\mathbf{p}<0,05 ; * *-\mathbf{p}<0,01 ; * * *-\mathbf{p}<0,001$ in comparison with male birds

\begin{tabular}{lcccc} 
Poultry species & $\begin{array}{c}\text { Quantity of } \\
\text { ejaculates }\end{array}$ & Sperm vagility, \% & $\begin{array}{c}\text { Live sperms with } \\
\text { undamaged } \\
\text { membranes, \% }\end{array}$ & $\begin{array}{c}\text { Pathological forms of } \\
\text { sperms, \% }\end{array}$ \\
\hline Male birds (7) & 35 & $85.24 \pm 1.48$ & $81.64 \pm 1.48$ & $9.03 \pm 0.36$ \\
\hline Quails (7) & 34 & $86.64 \pm 1.65$ & $83.96 \pm 1.43$ & $9.48 \pm 0.47$ \\
\hline $\begin{array}{l}\text { Guinea fowls } \\
\text { (7) }\end{array}$ & 37 & $81.68 \pm 1.48^{*}$ & $79.56 \pm 1.33$ & $13.16 \pm 0.55^{* * *}$ \\
\hline Male turkeys (7) & 36 & $75.22 \pm 2.59^{* *}$ & $71.06 \pm 2.18^{* * *}$ & $11.72 \pm 0.49^{* * *}$ \\
\hline $\begin{array}{l}\text { Goose-ganders } \\
\text { (7) }\end{array}$ & 39 & $63.75 \pm 2.01^{* * *}$ & $60.75 \pm 1.61^{* * *}$ & $15.06 \pm 0.49^{* * *}$
\end{tabular}

In order to obtain high fertility rates of ejaculates, it is very important that the percentage of sperm with intact membranes is as high as possible. Having studied the species differences in sperm with intact membranes, it was found that the highest percentage of sperm with intact membranes was found in the examined quails, which is $2.32 \%$ more than male birds, $4.4 \%$ more than guinea fowls, $12.9 \%$ more $(\mathrm{p}<0.001)$ than male turkeys and $23.21 \%$ more $(\mathrm{p}<0.001)$ than goose-ganders.

The analysis of the number of living sperm with intact membranes relative to the total number of sperm with rectilinear progression showed that in ejaculates of male birds of germ cells with intact membranes there was less total mobility by $3.6 \%$, in quails - by $2.68 \%$, in guinea fowls - by $2.12 \%$, in male turkeys - by $4.16 \%$, in goose-ganders - by $3 \%$.

The number of pathological forms of sperm was the smallest among male birds, which is $0.45 \%$ better than the quails, $4.13 \%$ less $(p<0.001)$ guinea fowls, $2.69 \%$ less $(p<0.001)$ male turkeys and $6.03 \%$ less $(p<0.001)$ goose-ganders. Thus, the smallest physiological number of sperm with pathological morphology is observed in cocks and quails - less than $10 \%$. The greatest 
IV International Scientific and Practical Conference "Modern S\&T Equipments and Problems in Agriculture"

physiological number of sperm with pathological morphology is observed in goose-ganders - about $15 \%$.

The main purpose of the study of poultry semen cryoresistance was to compare the existing cryotechnologies and diluents with the efficiency of the Belgorod technology for mammals, which we have developed and modified for freezing thawing of bird ejaculates. The results of the comparison of the efficiency of cryopreservation of poultry semen are presented in Table 2.

Table 2. Cryoresistance of poultry semen after freeze-thawing with different technologies $(\mathrm{M} \pm \mathrm{SEM}, \mathbf{n = 1 8 1})$. Nota bene. * - $\mathbf{p}<0,05 ; * *-\mathbf{p}<0,01 ; * * *-\mathbf{p}<0,001$ in comparison with

\section{German technology}

\begin{tabular}{|c|c|c|c|c|c|}
\hline \multirow[t]{2}{*}{$\begin{array}{l}\text { Poultry } \\
\text { species }\end{array}$} & \multirow[t]{2}{*}{$\begin{array}{l}\text { Quantity } \\
\text { of } \\
\text { ejaculates }\end{array}$} & \multicolumn{2}{|c|}{$\begin{array}{c}\text { German technology } \\
\text { (control dilution agent, } \\
\text { straws } / 0.25 \mathrm{ml}) \\
\end{array}$} & \multicolumn{2}{|c|}{$\begin{array}{c}\text { Belgorod technology } \\
\text { (experiment dilution agent, } \\
\text { pellets/ } 0.25 \mathrm{ml} \text { ) }\end{array}$} \\
\hline & & $\begin{array}{c}\text { Sperm vagility, } \\
\%\end{array}$ & $\begin{array}{l}\text { Live sperms with } \\
\text { undamaged } \\
\text { membranes, } \%\end{array}$ & $\begin{array}{c}\text { Sperm vagility, } \\
\%\end{array}$ & $\begin{array}{l}\text { Live sperms with } \\
\text { undamaged } \\
\text { membranes, } \%\end{array}$ \\
\hline $\begin{array}{l}\text { Male birds } \\
(7)\end{array}$ & 35 & $44.48 \pm 0.59$ & $20.88 \pm 0.55$ & $48.72 \pm 1.15^{* *}$ & $29.48 \pm 1.73 * * *$ \\
\hline Quails (7) & 34 & $47.18 \pm 1.01$ & $21.98 \pm 0.70$ & $50.42 \pm 1.37$ & $25.24 \pm 0.70 * *$ \\
\hline $\begin{array}{l}\text { Guinea } \\
\text { fowls (7) }\end{array}$ & 37 & $41.16 \pm 0.74$ & $19.30 \pm 0.65$ & $45.60 \pm 0.90 * * *$ & $28.18 \pm 2.10 * * *$ \\
\hline $\begin{array}{l}\text { Male } \\
\text { turkeys (7) }\end{array}$ & 36 & $39.13 \pm 1.36$ & $17.45 \pm 0.74$ & $46.17 \pm 1.04 * * *$ & $20.10 \pm 1.06^{*}$ \\
\hline $\begin{array}{l}\text { Goose- } \\
\text { ganders (7) }\end{array}$ & 39 & $33.09 \pm 1.01$ & $15.23 \pm 0.20$ & $42.22 \pm 1.26 * * *$ & $17.88 \pm 0.87 *$ \\
\hline
\end{tabular}

Species peculiarities of poultry semen cryoresistance are that the greatest number of sperm with straight forward movement after freezing thawing was observed in quails, That is $2.7 \%$ more $(\mathrm{p}<0.05)$ the mobility of sperm male birds, $6.02 \%$ more $(\mathrm{p}<0.001)$ guinea fowls, $8.5 \%$ more $(\mathrm{p}<0.001)$ male turkeys and $14.09 \%(\mathrm{p}<0.05)$ more activity of sperm hounds after thawing.

\section{Discussion}

The use of German technology and classical diluent for freezing poultry semen in the form of $0.25 \mathrm{ml}$ pellets provides low amounts of live semen with intact membranes. In cock ejaculates after thawing, only $20.88 \%$ of live sperm with intact membranes were obtained, which is $1.1 \%$ less from quail semen, $1.58 \%$ more from guinea fowls ejaculates, $3.43 \%$ more from male turkeys and $5.65 \%$ more $(\mathrm{p}<0.001)$ than in goose-ganders semen.

The efficiency of the Belgorod technology of semen cryopreservation, which we modified for semen of birds (Tkachev, et al., 2018a; Tkachev, et al., 2018b), provided better physiological characteristics of separated ejaculates of poultry after thawing than the German technology. The sperm motility of roosters after decontamination was $4.24 \%$ higher $(\mathrm{p}<0.01)$ than that of the 
German technology, while membrane conservation increased by $8.6 \%(\mathrm{p}<0.001)$. That agrees with the results of cryopreservation of bird semen, which are described in studies of foreign authors (Blanco, et al., 2007; Blesbois, Brillard, 2007).

Cryoresistance of quail semen was also 3.24\% higher than the conditions of application of Belgorod technology for mobility and $3.26 \%$ higher $(\mathrm{p}<0.01)$ for membrane stabilizing properties, as well as better than the literature data of foreign researchers (Brillard, Beaumont, Scheller, 1998; Cengiz, Yusuf, Ilker, 2013).

The efficiency of cryopreservation of sperm to the guinea fowls according to Belgorod technology in lined granules was $4.44 \%$ higher than the German analogue in terms of sperm motility ( $p<0.001)$, in terms of integrity of plasma membranes of germ cells by $8.87 \%(p<0.001)$. Physiological characteristics of thawed turkey semen, which was prepared according to Belgorod technology, surpassed the German analogue by $7.04 \%$ ( $\mathrm{p}<0.001)$ in terms of mobility, and by $2.65 \%$ in the integrity of sperm membranes.

\section{Conclusion}

Thus, our researches have shown that it is quite possible to receive safety of sperm of a poultry after freeze-thawing-defrosting more than $50 \%$. Unlike foreign researchers, who believe that it is very difficult to do in our experiments have a positive result. Comparison of the results of semen cryopreservation according to the modified Belgorod technology with the results of semen cryopreservation of different kinds of birds shows that the modified Belgorod technology is not only not inferior to foreign analogues, but even exceeds the latter by $2-9 \%$.

\section{References}

Blanco, J.M., Hofle, U., Moorhouse, R., Donoghue, A.M., Wildt, D.E. (2007). Improved avian sperm cryopreservation through comparative studies. Cryobiology, 55(3), 354-355.

Blesbois, E., Brillard, J.P. (2007). Specific features of in vivo and in vitro sperm storage in birds. Animal, 1, 1472-1481.

Brillard, J.P., Beaumont, C., Scheller, M.F. (1998). Physiological responses of hens divergently selected on the number of chicks obtained from a single insemination. Journal of Reproduction and Fertility, 114, 111-117.

Cengiz, Y., Yusuf, B., Ilker, Y. (2013). An evaluation of soybean lecithin as an alternative to avian egg yolk in the cryopreservation of fish sperm. Cryobiology, 67(1), 91-94. 
Dimitrov, S.G., Atanasov, V.K., Surai, P.F., Denev, S.A. (2007). Effect of organic selenium on turkey semen quality during liquid storage. Animal Reproduction Science, 100, 311-317.

Donoghue, A.M., Wishart, G.J. (2000). Storage of poultry semen. Animal Reproduction Science, $62,213-232$.

Douard, V., Hermier, D., Magistrini, M., Blesbois, E. (2003). Reproductive period affects lipid composition and quality of fresh and stored spermatozoa in turkeys. Theriogenology, 59, 753-764.

Dyubko, T.S., Egorov, M.I., Linnik, T.P. (2007). Fluorescent probes to study spermatozoa in cryoprotective media. Citology, 49(6), 521-526.

Fattah, A., Sharafi, M., Masoudi, R., Shahverdi, A., Najafi, A. (2017). L-Carnitine in rooster semen cryopreservation: Flow cytometric, biochemical and motion findings for frozen-thawed sperm. Cryobiology, 74, 148-153.

Froman, D. (2003). Deduction of a model for sperm storage in the oviduct of the domestic fowl (Gallus domesticus). Biology of Reproduction, 69, 248-253.

Hudson, G.H., Omprakash, A.V., Premavalli, K. (2016). Effect of semen diluents, dilution rates and storage periods on live and abnormal spermatozoa of pearl guinea fowls. Asian Journal of Animal and Veterinary Advances, 11(7), 411-416.

Iaffaldano, N., Meluzzi, A. (2003). Effects of dialysis on quality characteristics of turkey semen during liquid storage. Theriogenology, 60, 421-427.

Kotlowska, M., Dietrich, G., Wojtczak, M., Karol, H., Ciereszko, A. (2007). Effects of liquid storage on amidase activity, DNA fragmentation and motility of turkey spermatozoa. Theriogenology, 67, 276-286.

Kucera, A.C., Heidinger, B.J. (2018). Avian semen collection by cloacal massage and isolation of DNA from sperm. Journal of Visualized Experiments, 5, 132.

Linnik, T.P. (2003). Physical and chemical factors of cryodamages and cryoprotection of fowl spermatozoa in low temperature preservation cycle: Author's abstract of thesis of doctor of Biological Sciences. Belgorod, 36.

Linnik, T.P., Martynyuk, I.N. (2010). Approaches to creation of cryoprotective media for cryopreservation of avian sperm. Problems of Cryobiology and Cryomedicine, 20(2), 109-122. 
IV International Scientific and Practical Conference "Modern S\&T Equipments and Problems in Agriculture"

Long, J.A. (2006). Avian semen cryopreservation: what are the biological challenges? Poultry Science, 85(2), 232-236.

Lukasewicz, E., Chrzanowska, M., Jerysz, A., Chelmonska, B. (2004). Attempts on freezing the Greylag (Anser anser L.) gander semen. Animal Reproduction Science, 80(1-2), 163-173.

Mong Diep Nguyen, T., Alves, S., Grasseau, I., Métayer-Coustard, S., Praud, C. (2014). Central Role of 5'-AMP-Activated Protein Kinase in Chicken Sperm Functions. Biology of Reproduction, 91(5), 1-15.

Mosca, F., Madeddu, M., Sayed, A., Zaniboni, L., Cerolini, S. (2016). Combined effect of permeant and non-permeant cryoprotectants on the quality of frozen/thawed chicken sperm. Cryobiology, 73(3), 343-347.

Nishimura, H., Fan, Z. (2002). Sodium and water transport and urine concentration in avian kidney. Symposia of the Society for Experimental Biology, 54, 129-151.

Noirault, J., Brillard, J.P., Bakst, M.R. (2006). Spermatogenesis in the turkey (Meleagris gallopavo): quantitative approach in immature and adult males subjected to various photoperiods. Theriogenology, 65, 845-859.

Paranzini, C.S., Correia, L.D., de Camargo, L.S., Silva, K.M., de França, T.M., Silva, J.A., Veiga, N., de Souza, F.F. (2018). Feasibility of semen collection in red-winged tinamou (Rhynchotus rufescens) by manual stimulation and sazonality implications. Theriogenology, $107,36-40$

Partyka, A., Niżański, W., Bajzert, J., Łukaszewicz, E., Ochota, M. (2013). The effect of cysteine and superoxide dismutase on the quality of post-thawed chicken sperm. Cryobiology, 67(2), $132-136$

Seigneurin, F., Grasseau, I., Chapuis, H., Blesbois, E. (2013). An efficient method of guinea fowl sperm cryopreservation. Journal of Poultry Science, 92(11), 2988-2996.

Tkachev, A.V., Sheremeta, V.I., Tkacheva, O.L., Rossokha, V.I. (2017). Physiological relationship of erythrocyne antigens with indicators of horse spermogram. Fiziologichnyi Zhurnal, 63(1), 84-90.

Tkachev, A.V., Tkacheva, O.L., Rossokha, V.I. (2018a). Cytogenetic status of mares (Equus caballus) of Ukrainian riding breed influences their fertility. Agricultural Biology, 53(2), 302-308. 
IV International Scientific and Practical Conference "Modern S\&T Equipments and Problems in Agriculture"

Tkachev, A.V., Tkacheva, O.L., Rossokha, V.I. (2018b). Associated connection of erythrocitary antigens with characteristics of stallion semen after cryoconservation. Agricultural Biology, 53(4), 735-742.

Ushiyama, A., Priyadarshana, C., Setiawan, R., Miyazaki, H., Ishikawa, N. (2019). Membrane raftmediated regulation of glucose signaling pathway leading to acrosome reaction in chicken sperm. Biology of Reproduction, 1(4), 15-20.

Woelders, H., Zuilberg, C.A., Hiemstra, S.J. (2006). Animal genetic resources conservation in the Netherlands and Europe: poultry perspective. Poultry Science, 85, 216-222. 